InOedia $\begin{aligned} & \text { InMedia } \\ & \text { The French Journal of Media Studies }\end{aligned}$

9.1. $\mid 2021$

Film and TV-induced Tourism: Some Contemporary

Aspects and Perspectives

\title{
L. Ayu Sarawasti, Pain Generation: Social Media, Feminist Activism, and the Neoliberal Selfie
}

New York: New York University Press, 2021, 224 pages

\section{Claire Delahaye}

\section{CpenEdition \\ Journals}

\section{Electronic version}

URL: https://journals.openedition.org/inmedia/2864

DOI: 10.4000/inmedia.2864

ISSN: 2259-4728

Publisher

Center for Research on the English-Speaking World (CREW)

\section{Electronic reference}

Claire Delahaye, "L. Ayu Sarawasti, Pain Generation: Social Media, Feminist Activism, and the Neoliberal Selfie", InMedia [Online], 9.1. | 2021, Online since 15 January 2022, connection on 08 February 2022. URL: http://journals.openedition.org/inmedia/2864 ; DOI: https://doi.org/10.4000/inmedia.2864

This text was automatically generated on 8 February 2022

(c) InMedia 


\title{
L. Ayu Sarawasti, Pain Generation: Social Media, Feminist Activism, and the Neoliberal Selfie
}

New York: New York University Press, 2021, 224 pages

\author{
Claire Delahaye
}

\section{REFERENCES}

L. Ayu Sarawasti, Pain Generation: Social Media, Feminist Activism, and the Neoliberal Selfie, New York: New York University Press, 2021, 224 pages

1 Can feminists - and other activists - lead social media campaigns while escaping the neoliberal logic underpinning such digital spaces? This is the main question explored by Ayu Sarawasti, associate professor in women's studies at the University of Hawai i, in her new book. Indeed, Pain Generation: Social Media, Feminist Activism and the Neoliberal Selfie investigates different modes of online feminist activism, focusing specifically on the political potential of pain resulting from different forms of sexual violence, harassment or abuse. Using material collected online and a method based on feminist discourse analysis, this study scrutinizes "how feminist activism is structured and shaped by the neoliberal logic of this space and becomes neoliberalized and used for neoliberal purposes" (p. 20).

2 The book is divided in five chapters. Ayu Sarawasti's first chapter is a detailed introduction that thoroughly deconstructs the complex articulation between online feminist activism and the possible reproduction of neoliberal values, as neoliberalism is here understood as "a governing logic in social media" (p. 3). To better understand the relations between feminism and neoliberalism, Sarawasti mobilizes the three core concepts formulated by political scientist Michaele Ferguson: "liberation through capitalism," "privatization of political response," and "individualization of persistent gender inequality" (p. 5). She also adds that neoliberalism influences feminism with a 
focus on positive affect and the projection of happy subjects. This first chapter furthermore provides detailed definitions of the key concepts Sarawasti will use in her analysis, such as the neoliberal self(ie) gaze, which is a performance of the self and "is a mode of seeing and storifying the self on social media as a good neoliberal subject who is appealing, inspiring, and entertaining" (p.1). To try to demystify social media, Sarawasti uses the concept of phantasmagoria "to grasp the addictive and affective hold of social media" (p. 9) and to help us question media's self-professed neutrality. This notion encapsulates how social media, while being a performance, is based on the appearance of reality, and how it "floods our senses and anesthetizes us" (p. 10). Finally, because the feminist activists she focuses on are all Asian (North) American women, the author mobilizes the idea of "racial oscillation" to examine how racialization functions on social media, more specifically how Asian Americans are able to make their race visible or invisible on social media, which is linked to their history and their relation to whiteness. Sarawasti connects this to the neoliberal structure of social media, which makes race an individual issue, rather than a systemic one, and allows individuals to capitalize on it.

3 Each of her next three chapters focuses on one specific online activist: decolonial feminist poet rupi kaur, who moved to Canada when she was four and describes herself as a "Punjabi-Sikh immigrant woman," Japanese American violinist Mia Matsumiya, and Korean American comedian Margaret Cho. These chapters examine their feminist online campaigns, on Instagram for kaur and Matsumiya, and on Twitter for Cho, to highlight the limits of their activism. Throughout her book, Sarawasti is very careful not to focus her criticism on these individuals, but on the neoliberal structures that shape their practice, thereby showing how to use the very practices that she advocates in her last chapter.

4 The second chapter focuses on rupi kaur's feminist activism and makes three points: first, it explains how social media functions as a neoliberal space; second, it demonstrates how kaur uses racial oscillation as a "technology of neoliberal self(ie)" (p. 53); finally, it argues that phantasmagoria offers a valid critical perspective on social media, because it explains why the audience is prevented from doing activist work. Sarawasti studies how hegemonic neoliberalism distorts activism by investing in the self and in personal responsibilization, by promoting entrepreneurship of the self and a language of commodification.

5 The third chapter deals with Mia Matsumiya's Instagram campaign and the privatization of political response. Instead of asking the state or the system for change, the campaign turns to individuals and asks them to share their emotions on the social media platform. Sarawasti proposes the concept of the "sharing economy of emotions" to describe such process, which highlights the lack of institutional response to online violence towards women, but also prevents the dismantling and understanding of violence as a systemic issue as it solely focuses on individuals' experiences.

6 The fourth chapter analyzes Margaret Cho's \#12daysofrage campaign, in which sexual abuse is framed as an individual issue, not as a structural one. Sarawasti develops the concept of "silent testimony," to argue that choosing to remain silent might be a feminist strategy, and to deconstruct the belief that in order for one to heal, one has to voice trauma. She also convincingly debunks the notion that trauma is to be dealt with in an individual, and not collective way. For instance, shouldn't government or sexual violence perpetrators pay for women's therapy? Because of neoliberalism, women have 
to cope with gender inequality by working on themselves, in a context where agency is an unavoidable individual requirement, whereas it could be articulated as a collective issue.

7 Her last chapter explores possible forms of online feminist activism that do not subscribe to neoliberal values by focusing on the online activism of Sahar Pirzada, a Pakistani American Muslim woman, who uses social media to frame issues as systemic, to call for collective action and to invite people to mobilize and show up at marches, and in her practice uses engaged and critical pedagogy. Thanks to the example of Sahar Pirzada's online activism, Sarawasti theorizes the practice of "vigilant eco-love," which is collectively oriented and tries to end systemic oppression, and is presented as an "antidote to the neoliberal articulation of self-love" (p. 153).

8 This book is a compelling read for scholars interested in feminism, digital media, online activism, and for activists themselves. It reveals that many online practices or expressions used by activists - such as self-love for example -, have been neoliberalized. Ayu Sarawasti provides new concepts to think about the challenges of online feminist activism, and she suggests clear directions, solutions, and hope for social justice, so that feminist activism will not be exploited by the neoliberal machine. What makes this book very engaging is its thorough focus on the role of neoliberalism, but one might wonder if some of the complex dynamics described in the book might not be linked to other issues than only neoliberalism, for example the way that sexual violence is viewed as an individual issue and not a systemic one. The comprehensive study of the all-encompassing impact and influence of neoliberalism is nonetheless absolutely nuanced and definitely illuminating.

\section{AUTHORS}

\section{CLAIRE DELAHAYE}

Université Gustave Eiffel 